\title{
Assessment of Development of Early Childhood Based Between Plurality
}

\author{
Izzati \\ Department of Early Childhood Education \\ Faculty of Education, Universitas Negeri Padang \\ Padang, Indonesia \\ izzati_mpd@yahoo.co.id
}

\begin{abstract}
Early childhood assessment is a process undertaken to obtain accurate data on the overall progress of developmental dimensions and early childhood learning outcomes. This assessment is conducted with the aim of collecting data or evidence on the development and learning outcomes associated with early childhood development. This activity will provide an overview of what children can and can not do. This research is used qualitative design. The results of the assessment data used to evaluate the development of the child by comparing the results of the developmental assessment that the child has achieved. In addition, assessment aims to determine the progress of learning achieved by children in performing various developmental tasks as well as matters of interest and attention of children. For early childhood education assessment teachers are useful for determining appropriate actions and in accordance with the needs of children so that can be violated effective and efficient education programs.
\end{abstract}

Keywords: assesment; children; early childhood education

\section{EARLY CHILDHOOD DEVELOPMENT AND EDUCATION ASSESSMENT}

Early Childhood Education Assessment is a process of activities undertaken with the aim to collect data or evidence about the development and learning outcomes associated with early childhood development. This activity will provide an overview of what children can and can't do within the scope of the development according to the child's age level. The result of the assessment is the data used to evaluate the development of the child by comparing the results of the developmental assessment that the child has achieved with the level of development that the child must reach at a certain age so that it can be concluded that the quality of late, normal development or rapid development. In addition, assessment aims to determine the progress of learning achieved by children in performing various developmental tasks as well as matters of interest and attention of children. For teachers, early childhood education assessments are useful for determining appropriate actions and in accordance with the needs of children who are in a period of growth and development so that an effective and efficient education program can be implemented.

Based on the above description, general assessment and evaluation for early childhood can be categorized into two parts: assessment and evaluation of early childhood development and growth as well as assessment and evaluation of children's learning progress in obtaining various knowledge, skills and attitudes Which can be seen from the results of learning or performance. Implementation of these two assessment forms is not carried out separately because the development and outcomes of early childhood are two closely related issues.

A valid early childhood assessment presents comprehensive child development data with detailed descriptions of child strengths and weaknesses as well as significant events in the child's life. Type of authentic assessment. Based on this it can be identified the characteristics of the authentic assessment as follows: meaningful tasks, clear standards, reflections, transfers, formative, and integrative.

\section{CRITERIA FOR GROWTH ASSESSMENT AND EARLY CHILDHOOD DEVELOPMENT}

Assessment is an activity carried out with signs that refer to the child development criteria according to a certain age level. The description below provides an overview of the general criteria for the development of multiple intelligences.

Plural intelligence is a new invention and breakthrough in the field of intelligence discovered by Gardner [1]. Laurel [2] argues that plural intelligence is a recent development in the field of intelligence that explains matters relating to the pathways used by humans to be intelligent. 1) Verbal intelligence / language. Part of plural intelligence deals with the sensitivity to the sounds, structures, meanings and functions of words and languages that arise through the activities of conversation, discussion and reading. Furthermore, plural intelligence also appears in the ability to use words effectively, orally and in writing, including the ability to manipulate the syntax or structure of speech, phonology or sound in language, semantics or language meanings, and pragmatic dimensions or the practical use of language. 2) The intelligence of mathematical logic. Mathematical Logic intelligence is a part of plural intelligence that deals with sensitivity in searching and finding patterns used to perform calculations and abstract thinking and logical thinking and scientific thinking. The emergence of this intelligence can be seen from the ability to find differences in logic and numerical patterns, the ability to do a long and regular argumentation with a logical and scientifically structured mindset. The types of processes used in solving mathematical logic include: categorization, classification, inference, generalization, calculation and hypothesis testing. 
3) Intrapersonal intelligence. Plural intelligence is concerned with sensitivity in self-introspection, by comparing weaknesses and strengths within oneself. This intelligence enables the individual to have an accurate picture of himself (his own strength and his own limitations), awareness of inner feeling, intense, motivation, temperament and desires; And the ability to self-discipline, self-understanding and selfconfidence. (4). Interpersonal intelligence. Interpersonal intelligence is part of plural intelligence that is concerned with sensitivity in differentiating and responding to behaviors that others show. In this intelligence include the sensitivity of facial expressions, sounds and gestures, the ability to distinguish things from many types of interpersonal signs, kemamouan to act effectively against such signs pragmatically (e.g affecting a group of people to go with it in An action). (5). Naturalist Intelligence. Naturalist intelligence is part of the plural intelligence associated with sensitivity in appreciating nature and the environment. The emergence of this intelligence can be seen from the love of nature and the environment through various activities such as concern for the environment or the conservation of the surrounding natural environment. (6). Kinsethetik and body movement (bodilykinesthetic). Kinestethic intelligence is part of plural intelligence that is concerned with sensitivity and skill in controlling the coordination of body movement through coarse and fine motor movements, such as using tools skillfully, jumping, running, stopping abruptly skillfully in order to perform gymnastics or Dance movements, etc. Furthermore, this ability is manifested in the ability to use the full potential of the body to express ideas and feelings (e.g as actor, pantomime, as an athlete, or dancer, etc.), the ability to use the hands of producing or transforming things (e.g as sculptors, painters, Mechanic, surgeon). This intelligence also includes special body skills such as coordination, balance, strength, flexibility, speed, tactile and haptic abilities. (7). Musicalrhythmic intelligence. Musical-rhythmic intelligence is part of the plural intelligence associated with sensitivity in listening to sounds, music, and other sounds. The emergence of this intelligence can be seen from the ability to produce and appreciate the rhythm and music that can be realized in the perceived ability, for example as a music player, distinguish, for example as a music critic, and express, for example as musical actors of musical forms. This intelligence involves sensitivity to rhythm, melody, and other musical sounds of a musical creation. (8). Visual-spatial intelligence. Visual-spital intelligence is a plural intelligence associated with sensitivity in combining visual perception (eye) and mind and the ability to transform visual perception spatial as done in the activities of painting, designing patterns, designing buildings, etc. This intelligence involves sensitivity to the colors, lines, shapes, size, and relationships that exist between them. It includes the ability to visualize, and graphically depict visual and spatial ideas, and appropriately orient themselves into the spatial matrix.

The theory of multiple intelligences is often used by educators, both parents at home or teachers at school. Actually in some ways parents or teachers know instinctively that children learn in different ways and styles. This can be seen from the interest of one child with another child to an activity, there are children who show high enthusiasm but some are seen as not having the passion to do so [3].

An important goal in knowing various aspects contained in multiple intelligences is expected that educators can treat children according to their own ways and learning styles. As experienced educators often encounter various disappointments in the face of various children so that frustration arises in the face of them. This is natural, anxiety will affect the child's self-esteem. Understanding each child's individual intelligence and learning styles will help educators deal with children especially in teaching children in ways that best suit them, or in the easiest way they can master a lesson or job, capture information Or concepts or skills more quickly.

Multiple intelligence is a judgment that looks at descriptively how individuals use their intelligence to solve problems and produce things. This approach is a tool to see how the human mind operates the world, both concrete and abstract [4]. Thus in assessing and stimulating the intelligence of children, parents and teachers should carefully and carefully design a special method. The eight intelligences can be possessed by individuals only at different levels, besides this intelligence also does not stand alone sometimes mixed with other intelligences. The challenge for teachers and educators is to create a conducive learning environment for developing learning models that match the level of multiple intelligences that each child has. Provide preventive efforts to parents in developing their child's intelligence and in doing a task as a goal rather parents respect the success and failure in a particular field because each child has a different intelligence.

\section{TECHNIQUES AND PROCEDURES OF EARLY CHILDHOOD ASSESSMENT}

Early childhood development assessments can be undertaken in various forms and procedures appropriate to the needs of the desired growth and growth assessment. One of them is observation.

Observation is one form of proper procedure performed in the assessment of early childhood. Observation requires emphasis (focus) on behaviors displayed by the child, then the child's behavior is compared with the child's developmental criteria according to the child's observed age level. The results of this comparison are used as guidelines in determining whether the child is in determining whether the child is different in normal development (according to developmental criteria), below normal or above normal. Data relating to child behavior during observation can be recorded in various recording forms such as anecdotal record, running record, time sampling record, event sampling record, rating scale, check list and portofolio.

The portfolio is one that is a container for recording a variety of performance or concrete evidence of early childhood learning outcomes. Some of the reasons for using portfolios include: (a) Assist teachers to assemble concrete evidence of student learning outcomes in various forms of 
work; (b) Encourage the child to benefit from the learning outcomes achieved; (c) To assist teachers to understand the child's development profile more fully in their various areas of development; (d) Provide an overview of the development and learning outcomes of children interactively [5].

Portofolio as a container collecting performance of early childhood learning needs to be developed in full. This is . because the more complete the data used as a guide in assessing and evaluating the level of development or learning. outcomes that have been achieved by children.

Therefore, Mahyuddin [5] portfolio development should follow the following process. 1) Determining. objectives; 2) Collecting and compiling various data related to the learning outcomes of children; 3) Selecting the work that. will be the key to the progress of child development; 47. Determine the parts to be commented on; 5) Provide general conclusions on the development and achievement of child learning outcomes.

Presentation of children's work in portfolio form is arranged in the following format: (1) Presentation of children's work collection or performance; (2) Reflection and selfevaluation associated with the strengths and shortcomings of children based on the presentation of his work; and (3) Conclusion.

Assessment and evaluation of development and learning outcomes is an important and necessary activity in any activity related to early childhood education efforts. The results of the assessment and evaluation are used as guidance in determining the various forms of activities that are treated in early child development and education efforts. Various forms of activities undertaken in the assessment and evaluation of early childhood such as by observation. Data on the child's learning and learning outcomes obtained through observation can be recorded through such anecdotal records, running records, time sampling records, event sampling records and rating scales, checklists and portfolios [6].

\section{DISCUSSION}

Assessments should be done with a variety of methods. These methods have their respective advantages and disadvantages. Some assessment methods that can be used include checklist, rating scale, rubric, observations, and anecdotal notes. These methods can be used together to obtain a comprehensive picture of the development and learning of children in different perspectives [7]. Assessment can be directed to obtain a picture of the child in terms of the dimensions of child development and multiple intelligence. The dimensions of development that can be assessed include the dimensions of language development, mathematics, intellectual, social, emotional, self-concept, and motor. While plural intelligence can be assessed is linguistic intelligence, logical mathematical, visual-spatial, musical, kinesthetic, interpersonal, intrapersonal, existential and naturalistic. Assessment process conducted on children should be done naturally in order to obtain authentic data and illustrate the progress of the child as it is.

\section{References}

[1] Gadner,Howard (2002) Multiple Intelegency Kecerdasan Majemuk Teori dan Praktek. Jakarta. Interaksara.

[2] Schidt Laurel (2001) Seven Times Smarter: 50 Activities, Games, and Project to Develop the Seven Intelegences of Your Child. New York : Three River Press.

[3] Hartati (2005) Perkembanagn Belajar Pada Anak Usia Dini. Jakarta. Direktorat Jendral Pendidikan Tinggi.

[4] Sujanto (2006) Pembelajaran Untuk Anak TK. Jakarta. Direktorat Jendral Pendidikan Tinggi.

[5] Mahyuddin,Nenny (2008) Asesmen Anak Usia Dini. Padang. UNP Press.

[6] Amstrong,Thomas (2002) Setiap Cerdas Panduan Membantu Anak Belajar dengan Memanfaatkan Kecerdasan Majemuk. Jakarta. Gramedia Pustaka Utama.

[7] Suryana (2013) Dasar-dasar Pendidikan TK. UT. Kemendikbud. 